\title{
Nutrient Adequacy Of Lunch Sold To Pupils By Vendors In Some Selected Primary Schools In Ondo State, Nigeria.
}

\author{
Edun B. T., Adesanwo A. S. \\ Ogun State College of Health Technology, Ilese-Ijebu, Ogun State, Nigeria.
}

\begin{abstract}
The nutrient adequacy of school lunch has been proven to have profound effect on the nutritional status of school age children. This study investigated the nutrient adequacy of food sold to pupil by vendors primary schools in Owo metropolis. A total of 12 primary schools were randomly selected for the study, of which six of the schools were government owned and six were private. Foods sold to pupils for lunch were weighed, analysed and compared with recommended daily allowance. The result showed that the amount of money brought to school by private school pupils was \#20, this was found to be higher than those in government schools which was 10. Privates school respondents have adequate nutrient in their school lunch as energy, protein and fat were $43.5 \%, 39.5 \%$ and $29.5 \%$ of RDA respectively while the lunch bought by respondents from government owned schools was only able to meet $22 \%, 34 \%$ and $4.5 \%$ RDA for energy, protein and fat respectively. Vitamin C and Calcium intake in all schools studied were respectively, 4\% and 5\% in government schools and $8 \%$ and $6.5 \%$ in private schools.
\end{abstract}

Key words: School lunch, nutrient adequacy, vendors, nutrient intake, malnutrition

\section{Introduction}

Improvement in the nutrient intake of children has been recognized as an important issue that affects the health and well-being of individual (1). Many children are underweight, stunted, thin as a result of nutritional inadequacy, which prevent them from reaching their optimum potential (2) because nutrition is a foundation on which human progress in built (3). It is key to reaching the millennium development goal. It is however sad that malnutrition has continued to be a public health problem in developing countries where poor socio-economic conditions has continued to work in synergy with malnutrition. Children are one of the most vulnerable groups at great risk of malnutrition in these countries because nutrition has a direct impact on their growth and development as well as the nutritional status. Well-nourished children perform better in school; grow into healthy adult and in-turn give their children better start in life (3)

Moreover, malnutrition has been identified to affect the continue development of the children (4) and a veritable tool to reduce malnutrition among school children is to introduce good and effective school feeding programme that will improve the quality of food purchase by pupils in school. It has been reported that missing breakfast has a detrimental effect on cognition (5). Previous studies have shown that food purchase by school children during break time is poor in both quantity and quantity (6).

Also the average amount brought to school by pupils in primary school is five Naira (5) so small that food purchase with this amount has no significant effect on nutritional status (6)

A dearth of valid research of adequacy of food sold to pupils in southwest Nigeria is scanty. Therefore, this study aim at investigating the adequacy of food sold to pupils in some selected primary school in Owo metropolis.

\section{Methodology}

The study was carried out among school age children in primary schools in Owo in twelve (12) randomly selected primary schools of which six were privates and six were government schools. The lunch bought by the pupils from the vendors were weighed and recorded. The same were analyzed using the Nutri survey 2007 software. The nutrient composition of the foods was compared with RDA to ascertain if the lunch supplied 1/3 of RDA as recommended.

\section{Results}

Result shows that the lunch of pupils in private schools was able to meet $43.5 \%, 39.5 \%$ and $30 \%$ of energy, protein and fat respectively. Vitamin $\mathrm{C}$ and Calcium intakes for both government owned schools were respectively, $4 \%$ and $5 \%$ while intakes in private owned schools were $8 \%$ and $6.5 \%$ respectively. Test of significance also shows significance in the intakes between both government and private owned schools. 
Nutrient Adequacy Of Lunch Sold To Pupils By Vendors In Some Selected Primary Schools In Ondo

\begin{tabular}{|c|c|c|c|c|c|}
\hline Nutrient content & $\begin{array}{l}\text { Government } \\
\text { schools }\end{array}$ & \%RDA & Private schools & $\%$ RDA & Sig \\
\hline Energy [kcal] & 448.9 & $22 \%$ & 883.6 & $43.5 \%$ & 0.016 \\
\hline $\operatorname{Protein}[\mathrm{g}]$ & 12.3 & $34 \%$ & 32.55 & $39.5 \%$ & 0.032 \\
\hline Fat $[\mathrm{g}]$ & 3.25 & $4.5 \%$ & 20.35 & $29.5 \%$ & 0.106 \\
\hline Carbohydrate $[\mathrm{g}]$ & 85.9 & $29.5 \%$ & 129.7 & $44 \%$ & 0.009 \\
\hline Calcium $[\mathrm{mg}]$ & 99.6 & $5 \%$ & 88.5 & $6.5 \%$ & 0.014 \\
\hline Iron $[\mathrm{mg}]$ & 2.61 & $35.5 \%$ & 7.55 & $63 \%$ & 0.003 \\
\hline Zinc $[\mathrm{mg}]$ & 2.75 & $35.5 \%$ & 6.2 & $69 \%$ & 0.008 \\
\hline Vitamin C $[\mathrm{mg}]$ & 3.9 & $4 \%$ & 7.05 & $8 \%$ & 0.023 \\
\hline
\end{tabular}

\section{Discussion}

Determination of nutrient composition of food sold to pupils by vendors is a major important way to determine the nutrient intake among school age children that had their launch at school through the food they bought. Pupils in private schools were able to derive $43.3 \%$ of energy intake which was more than one third of the required RDA while the pupils in the public schools only met $22 \%$ of the RDA. According to Subar (1999)(8), launches must provide at least one - third of a child RDA for energy, protein, vit. A \& C and the minerals; Iron and Calcium. The result showed that pupils in private schools had adequate nutrients in launch food over pupils in government schools. Similar study(9) reported that children in most poor and developing countries are living on poor nutritional intake and that food are rarely modified at the household level to increase nutrient density to meet the needs of their members, and particularly children.

The majority (35\%) of pupils in public school brought ten naira ( 10$)$ food which was not enough to supply the required 33\% RDA this is in line with Olusanya (1997) (6)who said that food purchased by school children during launch is poor in both quantity and quality. These probably cause many of the children in public school particularly those that belong to low social economy to feed on low quality food.

There was low fat intake in both private and public schools studied although there is a general agreement that the diets of school - age children should include a variety of foods from each major group, not necessarily excluding any specific food because of its fat content overemphasis on fat - reduced diet during childhood has been linked to an increase in eating disorder and encourages an inappropriate "good food", "bad food" attitude (10).

Steering children toward healthful food, in school and at home, is likely to be more successful if children are exposed to nutritional education. Since children spend much of their young years in school, it is a great place to learn about positive, healthy eating habits (11) such education can help children understand why eating a proper diet will make them feel more efficiently one survey of school children highlighted the need for nutrition education. The study also showed that vitamin $\mathrm{C}$ and Calcium intake of respondents in both schools were extremely low this might be due to the fact that the vendors don't sell fruits and vegetables which out rightly exclude them from the lunch bought. This agrees similar study which showed that On the day of the survey, $40 \%$ of the children ate no vegetable, except for potatoes or tomato sauce; $20 \%$ ate as fruits: and $75 \%$ snacked at least twice. Another study showed that only $2 \%$ of about 3300 children 2 to 19 years old had met their recommended dietary allowance, from all five food guide pyramid groups. Clearly, the diets of many school age children can't stand general information, particularly with to fruit, vegetable, whole grain and their produce choices (12).

Also parent education or vendors and teacher education has been consistently shown to be critically important for child health. Nutrition and survival, evidence from various countries indicates that knowledge and practices are key pathways. Educated folks are likely to be more aware of nutrition, teach hygiene and health care (13). There is a significant difference on the pupil's nutrient intake which is reflected on the study that private schools pupils had higher nutrient intake. This might be due to the fact that more quantity of food is bought by the private school pupil but the study does not suggest good variety of nutritious food in private school.

\section{Conclusion}

The results of the study showed that nutrient intake of pupils in private school was higher and one-third of the RDA was met than government schools, however, the foods were deficient in calcium and vitamin C.

\section{Recommendation}

Sound nutrition throughout childhood promotes normal growth and development; facilitates academic and physical performance and helps to prevent diseases. Therefore, parents, vendors and other care givers working with children need to mindful of the nutrient requirements of children and importance of school lunch on their nutritional and health status. Also, school meals should be well planned to ensure good nutrient quality and vendors should be mandated to sell nutritious foods in schools. 


\section{Reference}

[1]. Tomkins A and Watson F. (1989). Malnutrition and infection. ACC/SCN Nutrition Policy Discussion paper NO. 5 UN standing committee on Nutrition, Geneva.

[2]. ACC/SCN, 2000. 4th Report on the world nutrition situation. Nutrition throughout the life cycle. United Nations Administrative Committee on Nutrition (ACC/SCN) in collaboration with International Food Policy Research Institute (IFPRI). pp: 4-12.

[3]. Veneman, A.M (2007) $30^{\text {th }} \mathrm{SCN}$ Annual session symposium on to end child hunger and under nutrition. UNICEF. Geneva

[4]. Pollit, E. McGregor, G. and Ani, N. (1995) The relationship between under nutrition and behavioral development in children. J. Nutr, 17.169-174

[5]. Benton, D and pry parker (1998). Breakfast blood glucose and Cognition. AM, J Clin. Nutr, 67; 772-778.

[6]. Olusanya, J.O (1997). Nutritional evaluation of mid day meals in primary schools in Ijebu. Non 11, Local government of Ogun State, Nigeria. Ila votech J, 1:214-220

[7]. Maxiya-Dixon, B., Oguntona, E. B., Harris, E., Nokoe, S., Manyong, V., Akinyele. I. O. and Sanusi, R. A. (2004). Nigeria food consumption and nutrition survey 2001-2003. Food Instruction Booklet. Ibadan, Nigeria. 62-64pp.

[8]. Subar, A. F., Adams, A., Oniango, O. R. and Kishor, S. (1998). Dietary sources of nutrient among U.S. Children, $1989-1991$. Brithish Journal of Nutrition 66:363-379

[9]. Dewey, K. G., Brown, K. H. (2003).Update on technical issues concerning complementary feeding of young children in developing countries and implications for intervention programs. Food Nutr. Bull, 24:5-28.

[10]. McBen, L.D., Miller, G. D. (1999). Enhancing the nutrition of America's youth. Journal of American College of Nutrition 18: 563569

[11]. Frary, C.D., Johnson, R. K., Wang, M. Q. 2004. Children and adolescents choice of foods and beverages high in added sugar are associated with key nutrients and food groups. J Adolescent Health.34(1):56-63.

[12]. Hamp, J. S. . Intakes of vitamin C, vegetables \& fruits, which school children are at risk, Journal of the American colleges of Nutrition $81: 582,1999$.

[13]. Gillespie, S. A. (2001). Attacking the double burden of malnutrition in Asia and the pacific Washington DC: International food policy research institute. 